\author{
Andreja Žele \\ Inštitut za slovenski jezik Frana Ramovša ZRC SAZU, Ljubljana
}

\title{
O predponsk(oobraziln)ih glagolih v slovenščini
}

Prispevek na slovenskih zgledih načenja vprašanje predponsk(oobraziln)ih vrednosti pri glagolih in soodvisnosti med predponskimi oz. predponsko-priponskimi obrazilnimi morfemi in predložnimi morfemi pri glagolih - slednje, tj. soodvisnost med glagolskimi obrazilnimi in predložnimi morfemi, se odraža v razporeditvi vidskosti, faznosti in prislovnosti.

Based on examples in Slovene the paper deals with the question of prefixal-formative values in verbal prefixed derivatives and the interdependence between prefixal formatives and prepositional morphemes in verbs. This interdependence is reflected in the distribution of aspectual, phasal, and adverbial features between prefixal formatives and prepositional morphemes.

Soodvisnost med predponsko-priponskimi obrazilnimi morfemi in predlogi kot predložnimi morfemi pri glagolih se odraža $\mathrm{v}$ razporeditvi vidskosti, faznosti in prislovnosti med glagolske obrazilne in predložne morfeme, tako da so vidskost, ${ }^{1}$ faznost in prislovna usmerjenost v predponsko-priponskem obrazilnem delu, predložni morfem glagola pa izraža prislovna razmerja. ${ }^{2}$

Ta obravnava glagolskih predponsk(oobraziln)ih tvorjenk se s skladenjskopomenskega in skladenjskobesedotvornega vidika osredinja na: (1) besedotvorne podvrste oz. pomensko- in skladenjskopodstavno utemeljene različice predponsk(oobraziln)ih tvorjenk s spremno vidskostjo, (2) razvrstitev sestavin pri dvo- ali večmorfemskem obraziljenju predponsk(oobraziln)ih tvorjenk in na (3) vzajemno vplivanost in soodvisnost sestavin znotraj obrazilno-predložnih razmerij pri predponsk(oobraziln)ih glagolih.

\footnotetext{
${ }^{1}$ Z vidika očitne težnje vseh glagolov po vidski parnosti ali vsaj po vidskem nasprotju predpone kot pomenonosne in besedotvorne prvine uvajajo vidska nasprotja; in zaradi nezmožnosti nekaterih glagolov, kot igrati, piti, peti, pisati, brati ipd., tvoriti sinonimni vidski par, kot spremstveno sestavino vključujejo še dovršnost (A. V. Isačenko 1960: 140, 166, 173, 175).

${ }^{2}$ Med drugimi npr. P. Piper (2001) tudi s povzemanjem tujih in domačih relevantnih ugotovitev opozarja na človeško jeziko(slo)vno koncepcijo v prvi vrsti prostora in na posledično oblikovanje in izražanje ( $\mathrm{z}$ besedo kot prostorsko metaforo) t. i. jezikovne slike konkretne in abstraktne prostorskosti oz. jezikovne prostorskosti - tj. na prehajanje od konkretne horizontalnosti do abstraktne vertikalnosti v smislu prostorskost - pripadnost - lastnost, npr. stati pred njim, priti pred njim, biti po uspehu pred njim, odskočiti od tal, odskočiti od včeraj, odskočiti od veselja, kar kaže tudi na visoko izomorfemskost različnih prostorskih izrazov kot t. i. prostorskih metafor in v njih opozarja še na posledično izofunkcionalnost prostorskih pomenskih kategorij s časovnimi, vidskimi, svojilnimi idr. kategorijami. Pri nas o tem največ A. Bajec 1959: 9, A. Vidovič Muha 1993: 164n in M. Merše: 1995.
} 
$1 \mathrm{~S}$ skladenjskopomenskega in skladenjskobesedotvornega vidika se predponsk(oobraziln)e tvorjenke v slovenščini lahko delijo na besedotvorne podvrste oz. pomensko- in skladenjskopodstavno utemeljene različice: ${ }^{3}$

(a) glagolske sestavljenke kot predponskoobrazilne modifikacijske tvorjenke s predponskim obrazilom (s pretvorbno vrednostjo prislova $\mathrm{v}$ skladenjski in pomenski podstavi, tudi faznost je časovnoprislovna), npr. prebosti, predelati, preplačati, pocingljati, obzidavati, razdati, priklicati, doklicati, steči, umiriti, zajokati;

(b) glagolske izpredložne (predponskoobrazilne) tvorjenke, ki so tudi (vsaj drugotno) modifikacijske (predponsko obrazilo je samo enakoizrazno s skladenjsko- in pomenskopodstavnimi predložnimi morfemi v frazeološkem glagolu) ${ }^{4}{ }^{\mathrm{npr}}$. izvleč $i$, nadgraditi, podmazati, pobarvati, odpoklicati ipd. Ravno pri izpredložnih tvorjenkah se lahko potrjuje trditev (prim. A. Bajec 1959: 9), da se iz iste starejše oz. prvotnejše "preverbialne rabe« razvijeta predponsko obrazilo (z usmerjenostjo glagolskega dejanja) in predložni morfemi (s prvotno prostorskim/časovnim razmerjem glagolskega dejanja);

(c) izpredložnozvezne izpeljanke (z dovršnim predložnim glagolskim primitivom npr. 'dati v roke / v knjigo / v račun', 'narediti do konca', 'izraziti v besedi / v pesmi' v skladenjski podstavi), v predponsko-priponskem obrazilu je vključena faznost, zaradi pretvorbe predloga iz skladenjske podstave $\mathrm{v}$ predpono pa se prislovna (prostorskočasovna) vrednost $\mathrm{v}$ smislu prislovne usmerjenosti in razmernosti porazdeli med predponsko-priponskim obrazilom in predložnim morfemom, npr. dokončati, vročiti, vknjižiti, vračunati, ubesediti, upesniti, predpasati, podceniti, pokrpati, popackati, razdeliti, obdavčiti, nadzidati; ukalupiti se v povprečje, včlaniti se v skupino sedmih, vprogramirati makroukaze $v$ notranji makrorom, vtiriti koga $v$ dejavnost;

(c1) izpeljanke s potencialno čistovidsko predpono (kot pretvorbo skladenjskopodstavnega 'narediti novo', 'postati molčeč' ipd.), npr. obnoviti, obmolkniti, osamiti, osvežiti, poveličati, zaceliti, zakrpati, začrtati. Tovrstne izpeljanke so še najbolj čistovidske. $^{5}$

${ }^{3} \mathrm{~V}$ smer natančnejše opredelitve besedotvornih vrst $\mathrm{v}$ slovenščini kaže že članek $\mathrm{J}$. Toporišiča, Sestavljenke in izpeljanke iz predložne/proklitične podstave v knjižni slovenščini, SR 21/1, 1973; isti avtor še dopolnjuje svoje ugotovitve v kasnejših razpravah (1996; 2000); problemsko pa J. Toporišiča dopolnjuje A. Vidovič Muha z razpravami $(1988 ; 1993 ; 2000)$, ki so upoštevane v tej delitvi.

${ }^{4}$ A. Bajec (1959: 9) povzema, da je preverbialna raba starejša od prepozicionalne, vendar tudi, da ko se je prvotni pomen v predponah oz. predponskih obrazilih postopoma izgubljal, ga je bilo lažje razbrati iz predložne rabe.

${ }^{5}$ A. V. Isačenko $(1960: 155,159)$ govori o večji ali manjši stopnji pomenske izpraznjenosti oz. abstraktnosti predpon oz. predponskih obrazil v slovanskih jezikih. O čistovidskosti oz. o perfektivizaciji s prefiksi $o-, p o-, n a-, i z-, z-/ s$ - pri Slovencih piše F. Ramovš (1952: 126), A. Bajec (1959: 21) pa o »goli perfektivizaciji« in o »obledelem prvotnem pomenu«. O tem tudi F. Jakopin $(1966: 177,179)$ : Toda vsa osnovna glagolska dejanja niso takšna, da bi prišla do izraza krajevno determinirajoča vloga preverbov, se je včasih adverbialna vsebina prefiksov na ta način približala ničli /.../ 179: »navidezno čisto aspektno razmerje«, npr. boljšati - izboljšati, in navsezadnje možnost sinonimije, npr. boljšati -izboljševati, kar se recimo potrjuje tudi v 
$\mathrm{Z}$ vidskega vidika in v okviru izpeljank tipa c) je npr. obeliti, očistiti < "narediti belo, čisto' bolj čistovidsko kot npr. počistiti < 'narediti čisto po (čem), pobeliti $<$ 'narediti belo po (čem)' ipd. O stopnji čistovidskosti odloča tudi pomenje določenega glagola v konkretnem jeziku. Čistovidskost tudi ne bi smela spremeniti glagolske predložne rabe.

Z vidika obrazilno-predložnih razmerij med prislovnostjo, faznostjo in vidskostjo je dobro poudariti že znano spoznanje, da besedotvorno-skladenjske vloge vida še niso vsestransko pojasnjene (prim. F. Bezlaj 1948, A. V. Isačenko 1960).

Glede na stopnjo pomensko-skladenjske podstavne relevantnosti predponsk(oobraziln)ih sestavin s pretvorbnega vidika delimo glagolske predponske tvorjenke na (1) predponsk(oobraziln)e $\mathrm{z}$ okoliščinskimi (predvsem prostorskimi in časovnimi, redko vzročnimi) in vrstnostnimi prislovi v pomensko-skladenjski podstavi in na (2) predponsk(oobraziln)e s samo modifikacijskimi oz. razvijajočimi prislovi načina oz. lastnosti in mere (količine oz. stopenjskosti). ${ }^{6}$ Glede na to, ali predponska obrazila oz. predpone s podstavno prostorsko-časovno pretvorbeno vrednostjo določeno korensko oz. besedotvornopodstavno sestavino glagolske predponsk(oobraziln)e tvorjenke (a) samo poudarijo ali pa (b) glagolskim besedotvornopodstavnim sestavinam dodajo novo prostorsko-časovno sestavino, ločujemo predponska obrazila oz. predpone, ki nastale glagolske predponsk(oobraziln)e tvorjenke (a) usmerjajo ali pa (b) preusmerjajo in s tem posledično omogočajo tudi bolj raznovrstna predložna razmerja; ${ }^{7}$ medtem ko se predponska obrazila oz. predpone z lastnostno ali stopenjsko modifikacijsko (pomensko-podstavno irelevantno) pretvorbno vrednostjo omejujejo samo na lastnostne/stopenjske spremembe glagolskega dejanja/doganja/stanja, s tem da ne vplivajo na že obstoječa možna predložna razmerja, temveč jih samo samozadostno zamejujejo. Pretvorbno razmerje med pomensko-skladenjsko in besedotvorno podstavo glagolske tvorjenke izpostavi tudi besedotvornopomenske vloge in vrednosti predponskih obrazil oz. predponskoobrazilnih morfemov - lahko ločujemo predponskoobrazilne tvorjenke s pomensko in vidsko vlogo predponskega obrazila, npr. prinesti $(<$ nesti), predponskoobrazilne tvorjenke s samo pomensko vlogo, npr. doplačati,

češčini (prim. Mluvnice češtiny (MČ) 2 1986: 182); modificiranje način poteka in izvršitev glagolskega dejanja, notranji ustroj glagolskega dejanja. Na možnost čistovidske oz. samovidske pomensko-skladenjske uporabe predponskih obrazil je opozorjeno npr. v češčini (Mluvnice češtiny 2 1986: 182) s predponskimi obrazili o-, vy-, na-, za-, z-, ze-, u-, po- (omládnout, vyléćit, napsat, zalátat, zhrozit se, zešedivěd, uvařit, pozlatit); v ruščini (V. V. Vinogradov 1947: 515, 533-536) so tovrstna predponska obrazila predvsem o-/ob-, po-, s-, $n a-, v z-u$-, vidski pari pa npr. krasnet'- pokrasnet', delat'-sdelat', pisat'-napisat', krast'-ukrast', budit'-razbudit' ipd.

${ }^{6} \mathrm{Z}$ vidika relevantnosti sestavine $\mathrm{v}$ pomenski podstavi povedi in hkrati tudi glede na konstitutivnost povedi A. Vidovič Muha opozarja tudi na različne stopnje modifikacijske vrednosti (1984: 153), nazadnje in najbolj eksplicitno v Slovenskem leksikalnem pomenoslovju (2000: 36-37).

${ }^{7} \mathrm{Z}$ vidika pomensko-skladenjske in pretvorbne relevantnosti je pomenljivo dodati, da sta v slovenskem jezikoslovju, npr. pri A. Vidovič Muha (1984; 1988: 7-25, 183-186), prostor oz. kraj in čas opredeljena tudi kot besedotvornopomenski sestavini. 
zaskočiti, preslišati (nasproti plačati, skočiti, slišati), ${ }^{8}$ določene predponskoobrazilne glagole, pri katerih zaradi visoke stopnje prislovne determiniranosti predponska obrazila ohranijo samo faznost, npr. (po-/za-)muditi se z, (za)riti (se) v, (za)vozlati (se) v, (po-/s-/za-)tlačiti $v$ ipd., ${ }^{9}$ in predponskoobrazilne tvorjenke s pomensko vlogo zadnjega predponskega obrazila $\mathrm{v}$ večstopenjsko tvorjenem sestavljenem/večmorfemskem predponskem obrazilu, ${ }^{10}$ npr. razprodajati, preprodajati (iz prodajati), doprinesti (iz prinesti). ${ }^{11}$ Da je faznost neke vrste časovna usmerjenost, potrjujejo tudi primeri kot napisati/zapisati/spisati na/v/po ipd.

Tudi s pomenskoskladenjskega vidika sama vidskost ni odločujoča, temveč je pomembna predvsem kombinacija pomenskih sestavin znotraj posameznega glagola, ${ }^{12}$ kar se jasno izraža zlasti pri glagolskih pomenih s široko pomenskoskladenjsko rabo, npr. pri obračunati z, obstati, odgovarjati (pog.), ostati, odpasti na/za, udariti (ekspr.), vreči (nav. ekspr.), vreči se na/v ipd. Odločilnost pomenskoskladenjske vloge izražajo tudi primeri kot Rad zapoje, Eno so zapeli (poudarjena 'faznost') :

Zapeli so vsega tri pesmi (poudarjena 'celostnost'): Ob večerih zapojejo (poudarjena 'ponavljalnost') : Ta zapoje kar želiš (poudarjena 'zmožnost'). ${ }^{13}$

${ }^{8}$ Predponska obrazila na dovršniško besedotvorno podstavo imajo pri novonastali tvorjenki zagotovo in predvsem pomensko(spreminjevalno) vlogo, npr. po-klekniti, po-končati, zapovedati, za-reči, za-skočiti, za-obiti, pre-slišati, do-pasti se, do-povedati, o-šiniti, pri-poročiti, pri-pustiti, s-posoditi, iz-povedati, iz-pustiti, s-končati, u-skočiti, u-pasti ipd.

${ }^{9}$ Pri določenih predponskoobrazilnih glagolih pa predponska obrazila ohranijo samo faznost, celotna prislovna vrednost, tj. tako prislovna usmerjenost kot razmernost, se prenese na predložne morfeme - dokaz za to je, da se z opuščanjem tovrstnih predponskih obrazil prav nič ne spremeni pomensko-skladenjska vezljivost, npr. (po)muditi se z, (za)muditi se z, (za)riti (se) v, (za) vozlati (se) v, (po-/s-/za-)tlačiti v ipd.

${ }^{10} \mathrm{~V}$ slovenski strokovni literaturi (prim. A. Bajec 1959: 105) se v teh primerih, največkrat s po- ali $i z / z$ - kot drugimi predponskimi obrazili v primerih kot po|razdelati, s|podriniti, uporablja izraz »dvojne sestavljenke«.

${ }^{11}$ Nastanek večmorfemskih predponskih obrazil v slovenščini npr. F. Ramovš (1952: 126) razlaga tudi tako, da so $\gg / n /$ ekateri prefiksi pomen glagola tako zelo spremenili, da se je glagol pomensko in formalno povsem ločil od prvotnega glagola, take glagole je zato jezik začel upoštevati kot simplekse in je z njimi tvoril nove zveze: dobiti : zadobiti /.../«.

${ }^{12}$ Prim. J. Orešnik (1994: 67-68) še s svojega vidika potrjuje, da »ima vsak glagol kot slovarska enota svojo lastno vidsko vrednost«, ki je v praksi določljiva na podlagi njegovega vidskega prispevka $\mathrm{k}$ njegovi najpreprostejši glagolski vezljivosti. Na vidsko vlogo in predvsem na vidske spremembe v t. i. »dogajalnem nizu« tudi v slovenščini opozarja M. Merše (2006: 185) z uresničevanjem t. i. »delnih vidskih pomenov«, tj. neke vrste vidska tekmovalnost dovršnika in nedovršnika v besedilu, povezana s konkretno besedilno aktualizacijo npr. s potrebo po poudarjanju dovršitve dejanja ali izražanju stanja po dovršitvi, npr. Sem že malical - Sem že pomalical, Smo mu prinesli vedno tudi malo sonca - Smo mu prinašali tudi vedno malo sonca ipd.

Medsebojno povezanost in soodvisnost med /ne/tvorjenostjo glagolov, njihovo vidskostjo in vrstnostjo in vezljivostjo predstavljajo študije ruskih glagolov (prim. T. Pettersson 1972), sicer pa so s stališča rusko-slovenske primerjave so skladenjsko zanimivi primeri stanja - dejanja, npr. rus. videt '(ploho, horošo) - uvidet' (kogo/čto) : slov. videti (slabo, dobro) - zagledati (koga/kaj), rus. Doroga prohodit'po lesu - Vremja prohodit' - Tri časa prohodil po ulice: slov. Cesta gre skozi gozd - Ćas mineva/beži - Tri ure je hodil po ulici.

${ }^{13} \mathrm{Tu}$ moram po T. Miklič (2007) povzeti vsaj to, da je romanski princip videnja/gledanja 
Pri enakozvočnih predponskih obrazilih in predložnih morfemih v okviru istega glagola gre za skladenjskopomensko komplementarnost v smislu prostorsko-časovne predponskoobrazilne usmernosti in predložne razmernosti, npr. iztrgati iz, oddaljiti se od, vdajati se v, zaleči za ipd. Prostorsko-časovna vrednost predložnega glagolskega morfema se ohranja tudi ob vedno pogostejšem vsebinskem ali ciljnem tožilniku (A. Žele 2001: 72-74): naplaviti na površje, nasnemavati zvok na že posneti slikovni material ('krajevna usmerjenost dejanja' z 'najvišjo relativno možno količino trajanja'), preprijeti se čez prsi ('prostorska razporeditev česa prek česa's 'celotno možno količino dejanja'), vrasti se/vraščati se v sistem, ('prostorska usmerjenost dejanja noter' z 'absolutno končanostjo dejanja'), zaprositi/zaprošati za dovoljenje ('faznost (začetnost enkratnega/večkratnega) dejanja').

Vsi zgornji primeri še potrjujejo, da je pogoj glagolske predložnomorfemske rabe prostorska (in posledično morebitna časovna) vrednost predlogov, sicer v nasprotnih primerih, z neprostorskimi (nečasovnimi) okoliščinami, o skladenjskopomenski navezanosti predloga na glagol oz. o t. i. predložnem glagolskem morfemu ne moremo govoriti - npr. zveze s prostorskim predložnim morfemom nakladati (na) tovornjak, igrati (na) kitaro nasproti zvezam z nevezljivimi neprostorskimi okoliščinami nakladati na novo, igrati na novo, napiti se/koga ipd.

1.1 Determiniranost je v glagolih implicirana prislovna usmerjenost oz. določnost, npr. reči, nesti. Tudi še z vidika vidskosti in tvorjenosti lahko ugotavljamo, da primarno dovršni netvorjeni glagoli vključujejo tudi pomensko določnost oz. determiniranost, ki je konkretna in usmerjena ciljnost, npr. dati, narediti, udariti, vreči, vzeti, pustiti, nesti, reči, videti, pasti, leči torej so zaznamovani s pomensko določnostjo oz. usmerjenostjo. Navadno pa je seveda konkretnejša pomenska determiniranost/usmerjenost s spremstveno dovršnostjo glagolom dodana s predponami oz. predponskimi obrazili. Predponskoobrazilna usmerjevalna vrednost (nasproti predložnomorfemski razmernosti) pa lahko sproži oz. omogoča spremembo vidskosti, faznosti, npr. $z a$ hoditi - zahajati, zagovoriti - zagovarjati; nagovoriti - nagovarjati, kar ima včasih za posledico celo naknadno spremembo pomena, npr. obhoditi-obhajati.

Pri določenih pomensko in zlasti prislovno determiniranejših glagolih, pri katerih je pomenska sestavina vsebinskosti ali namenskosti oz. ciljnosti že implicirana $\mathrm{v}$ glagolskem pomenu, je predložni morfem neobvezen; primeri za na in za: čakati (na) vlak, gledati (na) oblake, igrati (na) piščalko, odgovoriti (na) vprašano(Rd) : odgovoriti (na) vprašanje(Pd), paziti (na) otroke/zdravje, pritiskati (na) gumb, streljati (na) sovražnika, zadeti (na) oviro; loviti (za) rokav, popasti (za) nogo, poterjati (za) denar, prositi (za) pomoč.

1.2 Modifikacijska vrednost pri glagolih ne more biti uravnotežena med predponskim obrazilom in predložnim morfemom, temveč se težišče modifikacije določenega glagolskega pomena vedno prevesi bodisi na predponskoobrazilno stran bodisi na stran leksikaliziranega predložnega morfema, še dodatno potrjujejo primeri kot dati

v vprašalnici OD KOD? in slovenski princip videnja/gledanja KAM? - dovršniki torej usmerjajo pogled/pozornost na trenutno fazo prehoda, nedovršniki pa usmerjajo pogled/pozornost na trajajočo fazo vztrajanja ali ponavljanja v situaciji; o konkretnem izraženem mišljenju in o dejanski količini zajetega dejanja/dogajanja pa naj bi odločalo šele širše sobesedilu. 
čez - predati, vzeti čez-prevzeti, govoriti čez-ogovarjati, govoriti za-zagovarjati, priti do - pridobiti, s pomenskim razhajanjem, npr. hoditi ob - obhajati, padati nanapadati ipd.

1.3 Vidskost se v slovenščini razčiščuje tudi z večjim uveljavljanjem in kompletiranjem vidskih parov pri navadno prvotno dvovidskih glagolih, npr. grupirati - zgrupirati, maskirati : zamaskirati, minirati : zaminirati : zminirati, modernizirati : zmodernizirati, alarmirati : zalarmirati, materializirati : zmaterializirati, mobilizirati : zmobilizirati ipd. ${ }^{14}$

1.3.1 Pogosta prvotna dvovidskost glagolov na -(iz)ira-ti navadno omogoča tudi jasnejše razmerje med prislovnostjo, lastnostjo, faznostjo in vidskostjo. Pri določenih glagolih predponska obrazila lahko (1) samo še potrjujejo zlasti dovršnost brezpredponskoobrazilne različice, npr. prefotokopirati (fotokopirati dov./nedov.), zablokirati (blokirati dov./nedov.), zafiksirati (fiksirati dov./nedov.), zalarmirati (alarmirati dov./ nedov.), zbanalizirati (banalizirati dov./nedov.), zdisciplinirati (disciplinirati dov./ nedov.), zorganizirati (organizirati dov./nedov.), zreducirati (reducirati dov./nedov.), odreagirati (reagirati dov./nedov.), okvalificirati (kvalificirati dov./nedov.), (2) uvajajo zlasti ali samo dovršnost, npr. prekalkulirati, prekopirati, zabetonirati, zakodirati, zapakirati, zbombardirati, znervirati, razminirati, okarakterizirati, (3) poleg dovršnosti dodajajo glagolom novo prislovno/lastnostno ali vsaj fazno vrednost, npr. poagitirati, potelefonirati, prekritizirati, zakodirati, zašifrirati, zbirokratizirati, zdresirati, razšifrirati, vkomponirati, vkalkulirati, prigalopirati, primarširati ipd.

\section{Predponsko tvorbeno nizanje enomofemskih obrazil pri večstopenjskem ob- raziljenju}

Pomensko-skladenjska podstavna hierahija med prislovnimi določili/ dopolnili in lastnostnimi dopolnili se iz stavčnih povedi in besednih zvez pretvorbno prenaša tudi $\mathrm{v}$ hierarhično razvrstitev enomorfemskih predponskih obrazil v sestavljenem večmorfemskem predponskem obrazilu, tako se od korenskega oz. besedotvornopodstavnega jedra besede navzven $\mathrm{v}$ tvorbenih postopkih obrazilijo in razvrstijo naprej vrstnostna (okoliščinska oz. izprislovna) obrazila, nato vrednotenjsko lastnostna, sledijo količinska/stopenjska obrazila. ${ }^{15}$

\footnotetext{
${ }^{14}$ Pogoj je seveda nepsremenjen oz. ohranjen pomen. S primerjalnega vidika sta $z$ - in $z a-$ kot potencialni čistovidski predponski obrazili navajani npr. tudi v češčini (Mluvnice češtiny (MČ) 1986: 404-405) in slovaščini (1966: 414), za-je kot prvotno čistovidsko opredeljeno tudi v poljščini (S. Karolak 2001: 494); pri predponskem obrazilu po- je tudi v češčini (MČ 1986: 398) med najpogostejšimi pomeni izpostavljen pomen prehoda v novo stanje oz. lastnost; pri predponskem obrazilu pre- je tudi v češčini (MC 1986: 399) izpostavljen pomen spremembe; pri do- pa sta tako v slovaščini (1966: 409) kot v češčini (1986: 395) izpostavljena pomena dokončnosti in ciljnosti.

${ }^{15}$ Češka slovnica (Mluvnice češtiny (MČ) 1 1986: 394-395) sestavljena oz. večmorfemska predponska obrazila obravnava $\mathrm{z}$ vidika pomensko-skladenjskih sprememb, ki jih prispeva zadnje skrajnolevo predponsko obrazilo in ugotovitve so zelo podobne našim - skrajnolevo predponsko obrazilo izraža zlasti mero, tj. količino oz. stopnjo določene lastnosti, in lastnostno opredeljuje izraženi pomen.
} 
Kaže se, da imajo v slovenščini več možnosti za nadaljnjo višjo tvorbo oz. sploh višjo tvorjenost izpredložne izpeljanke; kot pomenska osnova za nadaljnje tvorjenje se mora upoštevati aktualno rabljena /ne/tvorjena beseda (v nadaljevanju označena z ločnico |) - v tej zvezi namreč lahko govorimo tudi o t. i. lažnih predponah oz. predponskih obrazilih (A. V. Isačenko 1960: 150), npr. do- pri dobiti (nasproti pri|dobiti), o- pri oprostiti, pred- pri predsedovati ipd. V nadaljnji tvorjenosti pa se navadno izmenično obrazilijo skladenjskopodstavni prislovi in predlogi, npr. dopreporaz|vrstiti < 'vrstiti (koga/kaj) postopoma ponovno dokončno' < 'dati (koga/kaj) v več vrst postopoma ponovno dokončno' (nasproti npr. prerazpovrstiti*), dopreporaz $\mid$ deliti < 'deliti (koga/kaj) na več strani postopoma ponovno dokončno' $<$ 'dati (koga/kaj) po delih na več strani postopoma ponovno dokončno' (nasproti doprerazpo|deliti), nasproti doprepo|razporediti < 'razporediti postopoma ponovno dokončno' < 'dati (koga/kaj) po redu v več smeri postopoma ponovno dokončno', ob tem še popre|razporejati (se), preraz|kosati; preu|vrstiti < 'dati (koga/kaj) v vrsto ponovno', dopopre|razmestiti < 'razmestiti (koga/kaj) ponovno v manjši meri, dokončno' < 'dati (koga/kaj) na različna mesta ponovno v manjši meri, dokončno', nadpreo|bremeniti < 'dati okoli (koga/česa) breme čez mero, preveč', preraz|kosati, (s)poraz|gubiti, upo|gibati, prena|kopičiti, dopre|naročiti ipd. Izhodiščna besedotvorna podstava za vsa nadaljnja možna predponska obrazila je izpredložna izpeljanka $\mathrm{s}$ skladenjskopodstavnim dati. Splošnopomenski netvorjeni in determinirani dati (kot skladenjskopodstavni v izpredložnozveznih izpeljankah) omogoča in dopušča širše oz. obsežnejše tvorbeno večstopenjsko predponsko obraziljenje - dopušča obraziljenje predvsem raznovrstnih udeleženskih razmerij, prostorskosti in različnih pre/o-vrednotenj; s skladenjskopomenskim dati, tudi zaradi njegove izrazite pomenske determiniranosti, je večstopenjska tvorjenost zelo jasno izražena. Kot del besedotvorne podstave je dati v tvorjenkah tipa porazpro|dati < 'dati (koga/kaj) čez koga/kaj na več strani postopoma'. Katero izmed predponskih obrazil pomenskoskladenjsko prevlada pri večstopenjski oz. višji predponskoobrazilni tvorjenosti pa potrdi uporaba določenega predloga oz. predložnega morfema (ločnica| ločuje izhodiščne pomenske /ne/tvorjenke od naknadno dodanih predponskih obrazil), npr. dopreporaz|deliti med/po/na/v, pre|usmerjati v, dopopre|razmestiti na/po/v/med, dopre|naročiti na/za, dopre|priporočiti $k / h / n a / z a$ ipd.

Pri pomensko specifičnejših glagolih (kot skladenjskopodstavnih v izpredložnih tvorjenkah) se predponsko obraziljenje zameji bolj na prislovnost (prostorsko/ časovno/načinovno/količinsko) in vrednotenje lastnosti - predvsem okoliščinsko usmerjenost oz. določnost pa razmerno dopolnjujejo in natačneje opredeljujejo še predlogi kot predložni morfemi. Precej produktivne so npr. izpredložne tvorjenke s pomensko determiniranimi glagoli v besedotvorni podstavi, kot je npr. nesti $\mathrm{v}$ prizanesti $<$ 'nesti $(\mathrm{komu} / \mathrm{čemu})$ za koga/kaj pri kom/čem', oponesti < 'nesti (komu/čemu) po $\mathrm{kom} / \mathrm{čem} \mathrm{o} \mathrm{kom/čem';} \mathrm{nekatera} \mathrm{predponska} \mathrm{obrazila} \mathrm{z} \mathrm{lastnostno} \mathrm{ali} \mathrm{stopenjsko} \mathrm{mod-}$ ifikacijsko (pomenskopodstavno irelevantno) pretvorbno vrednostjo se omejujejo samo na lastnostne/stopenjske spremembe glagolskega dejanja/doganja/stanja, tako da ne vplivajo na že obstoječa možna predložna razmerja, npr. obnesti se 'izkazati se', unesti se 'umiriti se' (nasproti npr., oponesti 'očitati', ponesti k/proti/po/na/v, prenesti na/v/po 'spraviti k/proti/na/v/po'). 


\subsection{Razvrstitev morfemov v predponsko-priponskem obrazilu}

Razvrstitev oz. prerazvrstitev morfemov v predponsko-priponskih obrazilih lahko povzroči skladenjskopomensko razločevalno vlogo in posledično $\mathrm{v}$ določenih skladenjskih pomenih možno samo nedovršno ali dovršno rabo, npr. predavati - predati, predajati se - predati se, zaobljubiti se, obhajati, sprevračati, nagovoriti/nagovarjati : prigovarjati ipd.

\section{Vzajemna vplivanost in soodvisnost sestavin znotraj obrazilno-predložnih razmerij pri predponsk(oobraziln)ih slovenskih glagolih}

Kako se prislovna predponsk/oobraziln/a usmerjenost/določnost ponovi še $\mathrm{v}$ predložnem prislovnem razmerju se potrjuje še pri posameznih glagolskih pomenskih skupinah, ki so hkrati tudi osnovne vezljivostne skupine slovenskih glagolov. ${ }^{16}$

$\mathrm{Z}$ vidika glagola je prislovnost, nasproti inherentni vidskosti, dodana adherentna lastnost, ki lahko z različnimi razmerji/odnosi do udeležencev (npr. prostorskočasovne spremembe ipd.) izraža tudi vrsto glagolskega dejanja, poimenovano tudi kot podvid (R. Simeon 1969: 73).

V spodnjih pomenskih skupinah bodo najprej upoštevani predponsk(oobraziln)i glagoli $\mathrm{v}$ kombinaciji najpogostejša predpona oz. predponsko obrazilo (po-, pre-, $\left.z a-, z_{-}, r a z-, o-, u-/ v-, d o-, p^{-} i_{-}\right)^{17}$ : najpogostejši predlog $(z a, z, o, v, p r i, n a)$.

Skladenjskopomenska vloga predložnega morfema je odvisna od glagolsko-samostalniške kolokacije; v vseh primerih pa predložni morfem ohranja prislovnost enakozvočni s predponskim obrazilom poudarja prislovno sestavino glagolske sestavljenke, neenakozvočni s predponskim obrazilom pa navadno dopolnilno natančno precizira vezljivo okoliščino oz. okoliščinsko hierarhično razmerje, npr. vezljivo-enakozvočni: oditi od, iziti iz, preiti prek, izstopiti iz, vstopiti $v$ nasproti vezljivo-neenakozvočnim oditi iz, iziti pri (založbi), preiti čez, izstopiti pri/na (zadnjih vratih), priigrati pri; primerjalno obširnejša je skupina priti blizu, priti do, priti $k$, priti v. Kot univerzalnejši izstopa nesmerni statični predlog oz. predložni morfem pri. Pri istih glagolskih sestavljenkah pa za jasnejšo predstavitev predponskoobrazilnega-predložnomorfemskega razmerja navadno navajamo še nekaj protiprimerov z nevezljivimi udeleženci oz. okoliščinami, npr. oditi $k / v$, vstopiti iz ipd. ${ }^{18}$

${ }^{16}$ Vezljivostna tipologija glagolskih sestavljenk, ki jih prinaša besedje v Slovarju slovenskega knjižnega jezika I-V (1970-1991), je obravnavana v članku A. Vidovič Muha, Glagolske sestavljenke - njihova skladenjska podstava in vezljivostne lastnosti ( $\mathrm{Z}$ normativnim slovensko-nemškim vidikom), Slavistična revija XLI/1 (1993), 161-192.

${ }_{17}$ Pri naštevanju prislovnih vrednosti najpogosteje uporabljanih predpon oz. predponskih obrazil so upoštevane razprave, naštete kronološko: A. Bajca (1959), M. Hajnšek Holz (1978), J. Toporišiča ( $\left.{ }^{4} 2000\right)$ in A. Vidovič Muhe (1993). Primerjalno-konstrastivno so kot najpogostejše izkazane in upoštevane tudi iste predpone in predponska obrazila $\mathrm{v}$ sodobnem ruskem jeziku, le v drugačni pogostnostni razvrstitvi (A. V. Isačenko 1960: 149).

${ }^{18}$ Možnosti napovedljivosti vezave iz morfemske sestave glagolov so bile že nakazane in deloma tudi obravnavane (J. Dular 1983). Izdelava skladenjskih podstav tvorjenk je omogočila natančnejšo obravnavo vezljivostnih posebnosti glagolskih izpeljank, glagolskih tvorjenk iz predložne zveze, glagolskih zloženk in glagolskih sestavljenk (A. Vidovič Muha 1988; 1993). 
3.1 V različnih skladenjskopomenskih rabah istega leksema, tj. glede na uporabljene pomene istega glagola, se samo še potrjuje predponska oz. predponskoobrazilna determinativna/usmerjevalna vloga in predložna prislovnorazmerna vloga.

Dvojo (predložno ali brezpredložno) vezavo omogoča dovolj široka pomenskost glagola - izbiramo med pomeni; v teh primerih gre za glagole oz. glagolske pomene, ki predvidevajo vsaj tri potencialne/možnostne udeleženske vloge s tremi udeleženci, od katerih je lahko eden neizražen, ker je sestavni del glagola ali izraženega (sestavljenega) udeleženca. Ta udeleženec pa lahko nastopa $\mathrm{v}$ dveh udeleženskih vlogah, ki se vsaj delno prekrivata oz. vzajemno dopolnjujeta - npr. prizadeto $\mathrm{z}$ dejanjem se lahko vsaj delno prekriva $\mathrm{z}$ izhodiščnim mestom dejanja ali s ciljem dejanja. Izbira udeleženca pa vzvratno vpliva na izbiro določenega glagolskega (skladenjskega) pomena, npr. izčistiti 'odstraniti/očistiti' madež z obleke : izčistiti 'odstraniti' madež : izčistiti 'očistiti' obleko ipd. In še primeri: dotočiti pijačo 'doliti' : dotočiti 'napolniti' kozarec, doliti vino : doliti kozarec, izmiti 'očistiti' rane : izmiti 'odstraniti' umazanijo iz rane, izpiti 'izprazniti' kozarec : izpiti 'odstraniti' vino iz kozarca, izčrpati vodo iz vodnjaka : izčrpati vodnjak, izčistiti madež z obleke : izčistiti obleko, izpiti vino : izpiti kozarec, izcediti sok: izcediti limono, izkrtačiti prah z obleke : izkrtačiti obleko, izpihati cevi : izpihati prah iz cevi, izterjati denar iz/od ljudi : izterjati denar, nabasati jabolka v košaro : nabasati košaro, oplesti ličje okrog steklenice : oplesti steklenico, oluščiti kožico s fižola : oluščiti fižol, odviti pokrov od steklenice : odviti steklenico, odkrhniti kos od krede: odkrhniti kredo, izpleti plevel: izpleti pšenico, iztrgati zvezek : iztrgati liste iz zvezka, naliti juho na krožnike : naliti krožnike, nametati misli na papir, nametati na papir, natlačiti jabolka v košare : natlačiti košare, vplačati prvi obrok za nov avtomobil: vplačati ( $z a=$ 'ohranja sestavinsko razmerje') nov avtomobil, vrezati navoj, posaditi gredo, vskočiti pri zadnji pesmi, dovesti do sklepa : dovesti ga do zdravnika, prikositi/dokositi do meje, namazati kruh : namazati marmelado : primazati ga, pripéti slavo/dovolj denarja : pripéti do ceste, zamešati testo : zamešati sestavine $v$ testo, zradirati papir : zradirati črte na papirju, zasaditi/posaditi gredo: zasaditi zelje na/v gredo ipd.

3.1.1 Vzorčne izhodiščne glagolske nadpomenke kot glagolske sestavljenke s skladenjskopodstavnimi (predložnomorfemskimi) delati, dati, biti, iti lahko vzorčno izražajo vezljivostni vpliv osnovnih pomenskih vrednosti predponskih obrazil 'faznost (začetnost/trenutnost/končnost)', 'prostorsko-časovna usmerjenost/rezultativnost (enkratna/večkratna)' in 'lastnost/mera (stopenjskost/količinskost)' in pomensko- in strukturnoskladenjsko pokrivajo vse glagolske sestavljenke. Sestavljenka je prehodna, ko je faznosti dodana kot razločevalnopomenska še ena izmed drugih dveh naštetih pomenskih sestavin, npr. pri izdati izraža 'usmerjenost dejanja' z 'rezultativnostjo': 'napraviti, da gre kaj odkod' - 'dati kaj ven': izdati blago iz skladiščca, izdati zdravila na recept; podobno še: izbezati/izbrizgati/izbruhniti ipd.; 'napraviti, da gre kaj odkod z določenim namenom': izdati terjatve; podobno še: izračunati/izter-

Slednje so vezljivostno obravnavane (A. Vidovič Muha 1993) v razmerju sestavljenka vpisati : sinhrono netvorjeni glagol pisati : (skladenjsko)podstavni pisati $v$, kjer je predstavljeno, kakšne lastnostne in številčne spremembe udeleženskih vlog lahko povzročajo predponska obrazila. 
jati/iztržiti ipd.; 'povedati, sporočiti, objaviti': izdati nekaj zadnjih novic; podobno še: izbrbrati/izčenčati/izgobezdati ipd.; pri zadati - -dati izraža 'usmerjenost', predponsko obrazilo za- pa 'začetnost': zadati komu globoke rane, zadati posestnikom veliko škodo; podobno še: zaklicati/zakričati/zavpiti ipd.; - pri obdati je tudi poudarjena smernost dejanja - 'narediti okrog česa/koga': obdati koga/kaj s čim; podobno še: obsijati/obsvetiti/obstopiti ipd.; - razdati - 'dati po delih': razdati revežem denar; podobno še: razčleniti/razdeliti/razdreti ipd.; pri predati se / podati se / vdati se/razdati se se jasno izraža prehod med prislovno vrednostjo in zgolj faznostjo - povratnoosebni zaimek se blokira spremembo prostorskosti, tako da predponsko obrazilo ohrani samo fazna pomena začetnosti in končnosti: predati se delu/jedi/žalosti, vdati se prošnji/obupu/alkoholizmu/sovražniku, razdati se družini/za otroke/za plemenite cilje ipd.

\subsubsection{Najpogostejša predponsko-predložna razmerja po glagolskih pomenskih skupinah}

Delitev po glagolskih (vezljivostnih) pomenskih skupinah glede na prevladujočo oz. prevladujoče pomenske sestavine pokaže, kako prevladujoča pomenska sestavina oz. prevladujoče pomenske sestavine vplivajo na izbiro predpone oz. predponskega obrazila in predložnega morfema. Ti vezljivostno opredeljeni predponsko-predložni glagoli po A. V. Bondarku (1978, 2001: 31-41) predstavljajo funkcijsko-pomensko polje uresničevanja in razporejanja kategorij prislovnosti, faznosti, naklonskosti in vidskosti v skladenjsko-besedotvornem izrazu konkretnih glagolov; izražanje naštetih slovničnokategorialnih pomenov pa je obvezno tako z jezikoslovnosistemskega vidika (tj. besedotvorno) kot $\mathrm{z}$ govorno-besedilnega vidika (prim. A. V. Bondarko 1978: 154). Po spodnjih skupinah so pogostejše glagolske sestavljenke in druge predložne tvorjenke razvrščene najprej na tiste, ki predponskoobrazilno (samo) poudarjajo pomenske sestavine in s tem ne spreminjajo vezljivosti in zato pričakovano ohranjajo iste predložne morfeme kot njihove brezpredložne ustreznice; isto velja tudi za predložne tvorjenke s predponami s samo fazno ali lastnostno/količinsko vrednotenjsko (predvsem načinovno in merno vrednostjo) ali vidsko vrednostjo - naprej so naštete te, za dvojno taktnico ( I| ) pa še predložne tvorjenke oz. sestavljenke, ki s predponskim obrazilom glagolom dodajajo dodatno pomensko (okoliščinsko oz. prislovno - predvsem prostorsko ali časovno) sestavino in s tem, glede na brezpredponskoobrazilni izhodiščni glagol, omogočajo dodajanje predloga oz. predložnega morfema in hkrati spreminjanje glagolske vezljivosti - za malo slovanske primerjave in kontrastive vključujem še ruske ustreznike. ${ }^{19}$

a) Specializirani glagoli telesnega in duševnega stanja: potrpeti pri потерпеть во время, в проиессе чего, prebivati na/v/pri-жить, находиться на /в /y, ostati na/v/pri- остаться на/в/y $\|$ vživeti se v-вжиться в ipd.

b) Specializirani glagoli ravnanja/upravljanja/ustvarjanja: raztrgati $\mathrm{v} / \mathrm{na}-$ разорвать в/на, razklati па - расколоть на, zadeti $v$ - попасть в, zajamс̌iti za-

${ }^{19} \mathrm{Za}$ pretehtani izbor ruskih ustreznikov se najlepše zahvaljujem dr. Tatjani Komarovi, lektorici ruskega jezika na FF v Ljubljani. 
гарантировать за, zabrenkati па-забренчать на, zaigrati na-заиграть на $\|$ razdvajati od-отделяться om, pohiteti z-nоспешить c, predložiti za-nредложить в качестве кого ipd.

b1) Glagole omogočanja nastajanja/nastanka česa: poprijeti za- взяться за, prestopiti $v$ - вступить в, prevesiti se v-склоняться к чему, изменяться, prihajati $v$ - приходить в, prehajati v-nревращаться в, vzpostaviti na/pri-восстановить

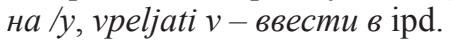

b2) Glagole $s$ poudarjeno pomensko sestavino premikanja: pobrskati po - покопаться по, poтеsti po/z - под/смести в/c, potovati po - ездить, nутешествовать по, popotovati ро - странствовать по, povzpeti se na/nad подняться на/над, podariti za - подарить для $\|$ pobirati po/v - взимать c/8, potegniti za-вступиться за ipd..

b3) Glagole s poudarjeno pomensko sestavino sonahajanja/sopojavljanja/pripadnosti: podedovati za/od/po - унаследовать om, pocukati za - подергать за, роdariti za - подарить на, počakati z-встретить c \| potiskati $v$ - загонять в, роsvetovati se s- посоветоваться c, pomagati z - помогать чем, pobrati po/iz/z/med - подобрать /подбирать по/из/с/среди ipd.

b4) Glagole s poudarjeno pomensko sestavino spremembe lastnosti: pokriti z покрыть чем, pogladiti $z$ - погладить чем, pokropiti $z$ - окропить чем, poтаstiti z - помазать жиром, pоškropiti z - побрызгать чем, razvaljati v/na - pacкатать Ha ipd.

Besedotvorna podstava npr. glagola nesti in njegove besedotvorne in pomensko-skladenjske zmožnosti samo še potrjujejo, da prostosko-časovna vrednost predpon/preponskih obrazil odpira možnost okoliščinskih predložnih razmerij, nasprotno pa metonimični pomenski prenosi v predponskih obrazilih z lastnostnim oz. količinskim ovrednotenjem ne uvajajo predložnih razmerij oz. jih celo ukinjajo: doprinesti $k$ 'prispevati' - вносить свой вклад, iznesti iz 'spraviti iz' - вывести из, іzродnеsti/spodnesti 'odstraniti izpod' - убрать из-noд, nanesti na 'spraviti na' - нанести на, obnesti se 'izkazati se' - оказаться, oponesti 'očitati' - укорять, ponesti $\mathrm{k} / \mathrm{h} /$ proti/po/na/v - нести к/no/нa/в, prenesti na/v/po 'spraviti na/v/po' - nоместить на/в/no, prenesti 'prestati' - перенести = выдержать, prinesti $\mathrm{k} / \mathrm{h}$ 'spraviti $\mathrm{k} / \mathrm{h}$ ' принести к, prizanesti 'prihraniti, pomagati' - пощадить, помочь, raznesti 'razširiti' - paсnространить, unesti se 'umiriti se' - успокоиться, vnesti $v$ 'spraviti v vključiti v' - внести в, zanesti na/v 'spraviti v/na' - занести в/на, zanesti se na 'opirati se na' - опираться на, znesti v/na 'spraviti v/na' znesti se nad 'spraviti se nad, ujeziti se na' - напасть (нападать) на, сердиться на ipd.

c) Specializirani glagoli govorjenja, razumevanja in mišljenja: poklicati ро - позвать кого, povprašati po/za - спросить кого, о ком, poagitirati za агитировать за, pobezati za - побежать за, poskrbeti za - позаботиться о, роimenovati z - назавать как (каким именем), podvomiti o-yсомниться в, zaprositi za-nопросить о (подать просьбу о) \| ројтоvаті za-nонимать, подразумевать как что/кого, pozabiti па - забыть о, ponašati se z - гордиться чем, razglasiti za - провозгласить кем, razčistiti z - разобраться с ipd. 
č) Specializirani glagoli s splošnim pomenom spremembe: povzpeti se $n a / v$ - подняться на/в, povečati se za/v - увеличиться на/в, požlahtnjevati z облагоражсиваться с помощьюю чего || razpasti na-распасться на ipd.

d) Specializirani glagoli premikanja: povzреti sе па - залезть, подняться на, poleteti $v$ - полететь в, preiti na - перейти $\kappa$, prejadrati na - припльтьь на парусном судне, prejadrati (čеz) осеап - перепльть (на паруснике) через океан, vpeljati v-ввести в курс дела кого, vskočiti v-замещать отсутствующего

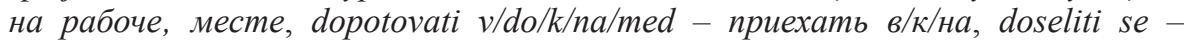
переселиться, izplaziti se iz - вылезть из, izleteti iz - вылететь из ipd.

3.1.3 Pogostnost uporabe $s e$ ob glagolih s prenesenim oz. metonimičnim predponskim obrazilom je vezana na izražanje samozadostnosti določenega delovanja oz. obstajanja, tako da zaimenski/zaimkovni morfem se/si z različno stopnjo pomenske izpaznjenosti ukinja prehodnost glagolskega dejanja na druge udeležence ali jo z zasedbo udeleženca - prizadeto/prejemnik omejuje oz. oži; visoka stopnja pomenske izpraznjenosti se omogoča tudi izbirno uporabo, npr. oddaljiti se/si- отдалиться, premisliti se/si - передумать, ираti si/se - осмеливаться/отваживаться. ${ }^{20}$

Po pogostnosti rabe so tovrstna predponska obrazila oz. predpone: po- (pobrskati - покопаться, poigrati-nоиграть); pre- (prečistiti-очистить, precvreti - (пере)прожарить, premlatiti - побить, prebičati - избичевать); za- (zagristi se - воодушевиться чем, zaklepetati se - заговориться, zamastiti - разжиреть); iz-/z- (skričati se - выкричаться, izsesati - высосать, spreobrniti se - изменить вероисповедание), raz- (razpeniti - вспенить, рассердиться (перен.), razsušiti - paсcохнуться, razveseliti - развеселиться), о- (očistiti - очистить, obledeti - побледнеть), u-/v- (ubeliti - cделать бельlм, ис̆іstiti - очистить, сделать чистымм), dо- (doreс̌i - договорить до кониа, обсудить, dopovedati-yбедить).

Pričakovano je najvišja stopnja (predvsem prostorsko-časovne) soodvisnosti med predponskimi obrazilnimi morfemi in predložnimi morfemi je pri glagolih telesnega in duševnega stanja, prav tako pričakovano pa je najmanjša stopnja soodvisnosti med predponskimi obrazilnimi morfemi in predložnimi morfemi pri glagolih $\mathrm{s}$ poudarjeno pomensko sestavino spremembe lastnosti.

\section{Tovrstne jezikovne težnje $v$ slovenščini}

Pri označevanju bolj razširjenega 'samodelovanja' se širijo predponska obrazila $z a-, z-/ s-, n a-$ in raz-s prostomorfemskim se, npr. zahoditi se, zajesti se, zaklepetati

${ }^{20}$ Raba potrjuje, da prostomorfemski se/si ni nikoli pomensko povsem izpraznjen ('povratnost' je stalna sestavina), zato ga glede na njegov (razločevalno)pomenski prispevek k pomenskosestavinskosti glagola delim na (a) se 'samopremikanja' v premikati se (nasproti: premikati koga/kaj), utopiti se (nasproti: utopiti koga/kaj), zgubiti se (nasproti: zgubiti koga/ kaj) ipd., (b) se 'samodelovanja' v razdajati se (nasproti: razdajati kaj), najesti se (nasproti: jesti kaj), dolgočasiti se (nasproti: dolgočasiti koga) ipd., (c) se 'stanja (počutja)' v bati se (nasproti: strašiti koga/kaj), veseliti se (nasproti: /raz/veseliti koga), jokati se, kesati se, kujati se, naveličati se, počutiti se, smejati se, zdeti se ipd., (č) se 'pojavnosti' v daniti se, svitati se, temniti se, kolcati se (komu), zehati se (komu) ipd., (d) se 'splošnovršilske navajenosti/navadnosti' v primerih kot Tod se hodi na Triglav ipd. 
se, zakoreniniti se, zagledati se, zahvaliti se; zjeziti se, zjesti se, shladiti se, spomniti se; nahoditi se, naplesati se, nagovoriti se, nagledati se, najesti se; razhoditi se, razjeziti se, razgovoriti se, razgledati se, razjesti se ipd.

Povečana glagolska sestavinskost in predložnomorfemskost izpostavi razmerje predponsko obrazilo : predložni morfem - povečuje se raba predložnih glagolskih tvorjenk tipa naplaviti na površje, nasnemavati zvok na že posneti slikovni material, vrasti se/vraščati se v sistem, ukalupiti se v povprečje, včlaniti se v skupino sedmih, vprogramirati makroukaze $v$ notranji makrorom, vtiriti koga $v$ dejavnost.

Pri vedno večji uporabi sestavljenk določena domača predponska obrazila kot $z a$ - in $z$-/s- ohranjajo (a) samo faznost (začetnost ali končnost), npr. zaasfaltirati, zamoralizirati, zamuzicirati, zmasakrirati, druga (b) prehod $\mathrm{v}$ novo stanje $\mathrm{z}$ novo lastnostjo, npr. po- v polastniniti, poskenirati, nekatera lahko posredno izražajo (c) družbene spremembe, npr. pre-: predefinirati ukaze, prefarati podružnico, preformulirati prastar red, preinterpretirati izide, prekategorizirati mejne prehode, preorganizirati svet, preparkirati avto, prestrukturirati gospodarstvo, preusposabljati ljudi ipd. Močno zastopano je tudi predponsko obrazilo do-, ki s svojo (č) 'dokončnostjo' oz. 'ciljnostjo' uvaja absolutno tožilniško vezavo in tako aktualizira družbeni trenutek, npr. doformulirati vse, dokapitalizirati podjetja, dokvalificirati presežne delavce ipd. $\mathrm{S}$ tem se tipizira tudi predvladujoča vrsta glagolskega dejanja - tako npr. sestavljenke $\mathrm{s}$ predponskim obrazilom po- navadno izražajo prehod $\mathrm{v}$ novo stanje, sestavljenke $\mathrm{z}$ obrazilom pre-spremembo dejanja in tiste s predponskim obrazilom do-dokončnost/ ciljnost dejanja.

Drugostopenjske tvorjenke se uporabljajo zaradi še dodatne zožitve prvotne pomenskosti glagola, npr. prednastaviti digitalni izenačevalnik, prenamestiti programsko opremo, preoštevilčiti stavbo.

\section{Sklepne ugotovitve}

- Soodvisnost med predponskimi obrazilnimi morfemi in predložnimi morfemi pri glagolih se odraža tako, da predpone oz. predponska obrazila izražajo prislovno določnost/usmerjenost (t. i. determiniranost in modifikacija), predlogi pa izražajo prislovna razmerja, ki natančneje določajo pomensko- in strukturnoskladenjsko vlogo glagolov v povedih.

- Razvrstitev predpon/predponskih obrazil s pomensko- in skladenjskobesedotvornega vidika rabe posredno izraža tudi višjo ali nižjo stopnjo univerzalnosti posameznega predponskega obrazila oz. njegovo zmožnost združevanja prislovnosti, lastnosti, faznosti in vidskosti.

Glede na to, ali predponska obrazila oz. predpone s podstavno prostorskočasovno pretvorbeno vrednostjo določeno korensko oz. besedotvornopodstavno sestavino glagolske predponsk(oobraziln)e tvorjenke (a) samo poudarijo ali pa (b) glagolskim besedotvornopodstavnim sestavinam dodajo novo prostorskočasovno sestavino, ločujemo predponska obrazila oz. predpone, ki nastale glagolske predponsk(oobraziln)e tvorjenke (a) usmerjajo ali pa (b) preusmerjajo in s tem 
posledično omogočajo tudi nova/dodatna predložna razmerja; medtem ko se predponska obrazila oz. predpone s čustveno-lastnostno-mernostno modifikacijsko (pomenskopodstavno irelevantno) pretvorbno vrednostjo omejujejo samo na lastnostne/ stopenjske spremembe glagolskega dejanja/doganja/stanja in da s tem samozadostno zamejujejo, tako da posledično ne vplivajo na že obstoječa možna predložna razmerja, npr. obnesti se 'izkazati se', unesti se 'umiriti se' (nasproti npr. oponesti 'očitati', ponesti $\mathrm{k} / \mathrm{h} /$ proti/po/na/v, prenesti na/v/po 'spraviti k/h/proti/na/v/po'); brez dodane prislovne usmerjenosti ostajajo tudi čistovidske oz. samovidske predpone oz. predponska obrazila, npr. približati, razdeliti, ohladiti - shladiti, boljšati - izboljševati/ poboljševati ipd.

- Delitev po glagolskih (vezljivostnih) pomenskih skupinah glede na prevladujočo oz. prevladujoče pomenske sestavine pokaže, kako prevladujoča pomenska sestavina oz. prevladujoče pomenske sestavine vplivajo na izbiro predpone oz. predponskega obrazila in predložnega morfema. Pričakovano je najvišja stopnja (predvsem prostorsko-časovne) soodvisnosti med predponskimi obrazilnimi morfemi in predložnimi morfemi je pri glagolih telesnega in duševnega stanja, npr. prebivati na/v/pri, prenočevati v/pri, preživotariti skozi, preživeti na/v/pri/skozi, obležati na/za, pri glagolih premikanja, npr. povzpeti se na, poleteti $v$, podrsovati pri, preiti na, prejadrati na, prejadrati (čez) ocean, preletavati po/na/čez, in pri glagolih s poudarjeno pomensko sestavino sonahajanja/sopojavljanja/pripadnosti, npr. podedovati za/od/po, pocukati za, podariti za, počakati z, poljubimkati z, poprijeti s/za, polegati/polegatil posedati v/na/po, politi po tleh, povasovati pri, omejiti na ipd.; prav tako pričakovano pa je najmanjša stopnja soodvisnosti med predponskimi obrazilnimi morfemi in predložnimi morfemi pri glagolih s poudarjeno pomensko sestavino spremembe lastnosti, npr. pokriti z, pogladiti $z$, pokropiti $z$, pomastiti z, poškropiti $z$, razvaljati v/na, in pri glagolih sprememb sploh, npr. povzpeti se na/v, povečati se za/v, požlahtnjevati $z$, pojedati se za, razpasti na, in še pri glagolih govorjenja, razumevanja in mišljenja, npr. poklicati po, povprašati po/za, poagitirati za, pobezati za, poskrbeti za, poimenovati $z$, podvomiti o, pofilozofirati o, zaprositi za, poklicati $k / v / n a$, zahvaliti se za ipd.

- Pri dvo- ali večmorfemskih sestavljenih predponskih obrazilih, nastalih po večstopenjski pretvorbi, se pretvorbno prenaša in tudi jasno izraža pomensko-skladenjska podstavna hierahija med prislovnimi določili/dopolnili in lastnostnimi dopolnili iz stavčnih povedi in besednih zvez $\mathrm{v}$ hierarhično razvrstitev predponskih enomorfemskih obrazil $v$ tvorbeno sestavljenem predponskem obrazilu višjetvorjene predponskoobrazilne tvorjenke, tako da se od korenskega oz. besedotvornopodstavnega jedra besede navzven, $v$ sestavljeno predponsko obrazilo, razvrstijo naprej vrstnostna (okoliščinska oz. izprislovna) predponska obrazila, nato vrednotenjsko-lastnostna, sledijo količinska/stopenjska predponska obrazila, npr. pre-raz- (prerazdeliti), s-pre(spregledati, spregovoriti, spreklati se, spreobrniti, spremešati); možne so tvorjenke tudi s tremi in celo več pretvorbno nanizanimi predponskimi obrazili (v kombinaciji s predponami), npr. dopreporazvrstiti, preporazdeliti, sporazgubiti ipd.

Posebnosti v tvorbeno večstopenjskem predponskem obraziljenju (znak $>$ kaže smer razvoja in rabe): - težišče predponskoobrazilnega pomena se premakne na zadnje skrajnolevo predponsko obrazilo, npr. sprevreči : prevreč $i$, doprinesti : prinest $i$, 
predomisliti se 'premisliti se' : domisliti se, oprijemati : prijemati, vpoklicati : poklicati, - zadnje skrajnolevo predponsko obrazilo ima predvsem vidsko oz. (̌se) fazno vrednost, npr. postrgati : strgati, - zadnje skrajnolevo predponsko obrazilo zaradi običajne pomenske prevlade pogosto ukinja obkorenski morfem, npr. prepogibati $>$ pregibati, razpodeliti $>$ razdeliti, predomisliti se $>$ premisliti se, pripoznati $>$ prizna$t i$, zapričeti $>$ začeti, in obratno, npr. pridodajati $>$ dodajati, zaukazati $>$ ukazati, spremisliti $>$ premisliti, - zamenjuje se zadnje skrajnolevo predponsko obrazilo, npr. započasniti > upočasniti; vpostavljeno je pomensko-besedotvorno razmerje pomensko sicer enakovrednih glagolov, npr. razpodeliti* (star.) : razdeliti : porazdeliti ipd.

\section{Literatura}

Bajec, Anton, 1959: Besedotvorje slovenskega jezika IV: Predlogi in predpone. Ljubljana: SAZU.

Bezlaj, France, 1948: Doneski k poznavanju glagolskega aspekta. Časopis za literarno zgodovino in jezik I, 199-220. Ljubljana.

Bondarko, Aleksander Vladimirovič, 1978: Grammatičeskoe značenie i smysl. Leningrad: Nauka.

- - 2001: K voprosu sisteme analiza aspektov jazyka i reči v funkcional'nnoj grammatike. Tradicionnoe i novoe v russkoj grammatike. Sbornik statej pamjati Very Arsen'evny Belošapkovoj. Moskva: INDRIK.

Daneš, František idr., 1987: Větné vzorce v češtině. Praha: Academia.

Dular, Janez, 1983: Napovedljivost vezave iz morfemske sestave glagolov. Slavistična revija $\mathrm{XXXI} / 4,283-287$. Ljubljana

Hajnšek Holz, Milena, 1978: O pomenih slovenskih predpon. XIV seminar slovenskega jezika, literature in kulture, 33-58. Ljubljana.

Isačenko, Aleksander Vasiljevič, 1960: Grammatičeskij stroj russkogo jazyka v sopostavljenii s slovackim. II Morfologija. Bratislava: Izdatel'stvo slovackoj akademii nauk.

Jakopin, Franc, 1966: K tipologiji slovenskega in ruskega glagola. Jezik in slovstvo $\mathrm{XI} / 6,176-182$. Ljubljana.

- - 1971: Glagoli premikanja v slovenščini in ruščini. VII. seminar slovenskega jezika, literature in kulture, 1-12. Ljubljana.

Karolak, Stanisław, 2001: Od semantyki do gramatyki. Wybór rozpraw. Warszawa: Instytucia Slawistyki PAN.

Mel'čuk, Igor Andrejevič, 1995: Russkij jazyk v modelu smysl <> tekst. Moskva Wien: Slawistischer Almanach Sonderband 39.

Merše, Majda, 1995: Vid in vrstnost glagola v slovenskem knjižnem jeziku 16. stoletja. Ljubljana: SAZU.

- - 2006: Glagolski vid v povezavi z drugimi glagolskimi kategorijami v knjižnem jeziku 16. stoletja. Slavistična revija LIV. Slovensko jezikoslovje danes (Posebna številka), 177-191. Ljubljana.

Miklič, Tjaša, 2007: Metafore o načinih gledanja na zunajjezikovna dejanja v obravnavanju glagolskega vida. Slavistična revija LV/1, 85-103. Ljubljana. 
Mluvnice češtiny (MČ 1 - Fonetika, Fonologie, Morfonologie a morfemika, Tvoření slov, MČ 2 - Tvarosloví). Ur. Miloš Dokulil, Miroslav Komárek idr. 1986. Praha: Academia. 566 str., 536 str.

Orešnik, Janez, 1992: Udeleženske vloge v slovenščini. Ljubljana: SAZU.

- - 1994: Slovenski glagolski vid in univerzalna slovnica. Ljubljana: SAZU.

- - 1996: Nauk novejše slovenistike o povedkovem prilastku. Razprave drugega razreda SAZU XV, 255-267. Ljubljana.

Pettersson, Tom, 1972: On Russian Predicates (A Theory of Case and Aspect). Göteborg.

Piper, Predrag, 22001: Jezik i prostor. Beograd: Biblioteka XX vek.

Ramovš, Fran, 1952: Morfologija slovenskega jezika. Skripta, prirejena po predavanjih prof. dr. Fr. Ramovša v 1. 1947/48, 48/49, ur. B. Pogorelec, P. Merku in M. Sovre. Ljubljana: DZS.

Slovar slovenskega knjižnega jezika I-V (SSKJ), 1970, 1975, 1979, 1985, 1991. Ljubljana: DZS.

Simeon, Rikard, 1969: Enciklopedijski rječnik lingvističnih naziva (na 8 jezika) I-II. Zagreb: Matica hrvatska.

Švaćko, Vanja, 1993: Funkcija i status prijedložnih izraza. Rasprave Zavoda za hrvatski jezik XIX, 353-361. Zagreb.

Toporišič, Jože, 1965-1970: Slovenski knjižni jezik I-IV (SKJ). Maribor: Obzorja.

- - 1967: Poizkus modernejše obravnave glagolskih kategorij. Jezik in slovstvo XII, 119-127. Ljubljana.

- - 1973: Sestavljenke in izpeljanke iz predložne/proklitične podstave v knjižni slovenščini. Slavistična revija XXI/1, 105-112. Ljubljana.

- - 1992: Enciklopedija slovenskega jezika (ESJ). Ljubljana: Cankarjeva založba.

- - 1996: Glagolske »sestavljenke« iz zveze glagol + predložna zveza. Razprave drugega razreda SAZU XV, 109-123. Ljubljana: SAZU.

- ${ }^{4}$ 2000: Slovenska slovnica (SS). Četrta, prenovljena in razširjena izdaja. Maribor: Obzorja.

Vidovič Muha, Ada, 1984: Nova slovenska skladnja J. Toporišiča. Slavistična revija XXXII/2, 142-155. Ljubljana.

- - 1988: Slovensko skladenjsko besedotvorje ob primerih zloženk (SSB). Ljubljana: Znanstveni inštitut Filozofske fakultete in Partizanska knjiga.

- - 1993: Glagolske sestavljenke - njihova skladenjska podstava in vezljivostne lastnosti (Z normativnim slovensko-nemškim vidikom). Slavistična revija XLI/1, 161-192. Ljubljana.

- - 2000: Slovensko leksikalno pomenoslovje. Govorica slovarja. Ljubljana: Znanstveni inštitut Filozofske fakultete.

Vinogradov, Viktor Vladimirovič, 1947: Russkij jazyk (grammatičeskoe učenie o slove). Moskva, Leningrad.

Žele, Andreja, 2001: Vezljivost v slovenskem jeziku (s poudarkom na glagolu). Ljubljana: Založba ZRC, ZRC SAZU.

Prispelo junija 2008, sprejeto oktobra 2008

Received June 2008, accepted October 2008 


\section{O predponsk(oobraziln)ih glagolih v slovenščini}

Razvrstitev predpon/predponskih obrazil z vidika rabe posredno izraža tudi višjo ali nižjo stopnjo univerzalnosti posameznega predponskega obrazila oz. njegovo zmožnost združevanja prislovnosti, lastnosti, faznosti in vidskosti.

Soodvisnost med predponskimi obrazilnimi morfemi in predložnimi morfemi pri glagolih se odraža tako, da predpone oz. predponska obrazila izražajo prislovno določnost/usmerjenost (t. i. determiniranost in modifikacija), predlogi pa izražajo prislovna razmerja, ki natančneje določajo pomensko- in strukturnoskladenjsko vlogo glagolov v povedih.

Glede na to, ali predponska obrazila oz. predpone s podstavno prostorsko-časovno pretvorbeno vrednostjo določeno korensko oz. besedotvornopodstavno sestavino glagolske predponsk(oobraziln)e tvorjenke (a) samo poudarijo ali pa\

(b) glagolskim besedotvornopodstavnim sestavinam dodajo novo prostorsko-časovno sestavino, ločujemo predponska obrazila oz. predpone, ki nastale glagolske predponsk(oobraziln)e tvorjenke (a) usmerjajo ali pa (b) preusmerjajo in s tem posledično omogočajo tudi nova/dodatna predložna razmerja; medtem ko se predponska obrazila oz. predpone z lastnostno ali stopenjsko modifikacijsko (pomensko-podstavno irelevantno) pretvorbno vrednostjo omejujejo samo na lastnostne/stopenjske spremembe glagolskega dejanja/doganja/stanja in da s tem samozadostno zamejujejo in hkrati ne vplivajo na že obstoječa možna predložna razmerja, npr. obnesti se 'izkazati se', unesti se 'umiriti se' (nasproti npr., oponesti 'očitati', ponesti k/h/proti/po/ na/v, prenesti na/v/po 'spraviti $\mathrm{k} / \mathrm{h} / \mathrm{proti} / \mathrm{na} / \mathrm{v} / \mathrm{po}$ '); brez dodane prislovne usmerjenosti ostajajo tudi čistovidske oz. samovidske predpone oz. predponska obrazila, npr. približati, razdeliti, ohladiti - shladiti, boljšati - izboljševati/poboljševati ipd.

Pričakovano je najvišja stopnja (predvsem prostorsko-časovne) soodvisnosti med predponskimi obrazilnimi morfemi in predložnimi morfemi je pri glagolih telesnega in duševnega stanja, npr. prebivati na/v/pri, prenočevati v/pri, preživotariti skozi, preživeti na/v/pri/skozi, obležati na/za, pri glagolih premikanja, npr. povzpeti se na, poleteti $v$, preletavati po/na/čez, in pri glagolih s poudarjeno pomensko sestavino sonahajanja/sopojavljanja/pripadnosti, npr. podedovati za/od/po, pocukati za, podariti za, počakati z, povasovati pri, omejiti na ipd.; prav tako pričakovano pa je najmanjša stopnja soodvisnosti med predponskimi obrazilnimi morfemi in predložnimi morfemi pri glagolih s poudarjeno pomensko sestavino spremembe lastnosti, npr. pokriti $z$, pogladiti $z$, in pri glagolih sprememb sploh, npr. povzpeti se na/v, povečati se $z a / v$ ipd.

Pri razvrstitvi predponskih obrazil pri dvo- ali večstopenjskem obraziljenju predponsk(oobraziln)ih tvorjenk se pretvorbno prenaša in tudi jasno odraža pomensko-skladenjska podstavna hierahija med prislovnimi določili/dopolnili in lastnostnimi dopolnili - težišče predponskoobrazilnega pomena se premakne na zadnji skrajnolevi predponskoobrazilni morfem, npr. sprevreči : prevreč $i$, doprinesti : prinest $i$, predomisliti se 'premisliti se' : domisliti se, oprijemati : prijemati, vpoklicati : poklicati; - zadnji skrajnolevi predponskoobrazilni morfem (navadno zaradi vsaj delnega pomenskega prekrivanja) pomensko prevlada in zato $\mathrm{v}$ rabi (postopoma) ukinja 
obkorenski morfem, npr. prepogibati $>$ pregibati, razpodeliti $>$ razdeliti, in obratno, npr. pridodajati $>$ dodajati, zaukazati > ukazati; lahko je vzpostavljeno pomenskobesedotvorno razmerje pomensko sicer enakovrednih glagolov, npr. razpodeliti*(star.) : razdeliti : porazdeliti ipd.

\section{On Prefixed Verbs in Slovene}

The distribution of prefixes/prefixal formatives according to their usage indirectly reflects the higher or lower degree of universality of a particular prefixal formative or its potential to incorporate adverbial, qualitative, phase, and aspectual features.

The interdependence between prefixal morphemes and prepositional morphemes in verbs is reflected in prefixes/prefixal formatives expressing an adverbial definiteness/orientation (the so-called determinacy and modification), and prepositions expressing adverbial relations, which specify the semantic-syntactic and structural role of a verb in the sentence.

Prefixal formatives or prefixes with a spatial-temporal transformational value can be divided into two groups: (a) those that only emphasize and thus direct a particular root- or syntactic-base component of a verbal prefixed derivative, and (b) those that redirect and consequently allow for new/additional prepositional relations, and thus add a new spatial-temporal component to the word-formational components of the verb. Prefixal formatives or prefixes, which have a modifying (semantico-syntactically irrelevant) transformational value of property or degree, on the other hand, are limited only to qualitative/degree changes of the verbal action/occurrence/state, and consequently self-limit and at the same time fail to influence the already existing potential prepositional relations, e.g., obnesti se 'izkazati se' ('to prove successful'), unesti se 'umiriti se' ('to calm down') (vs. oponesti 'očitati' ('to reproach'), ponesti $\mathrm{k} / \mathrm{h} /$ proti/po/na/v, prenesti na/v/po 'spraviti k/h/proti/na/v/po' ('to get to/towards/on/ in')); aspectual prefixes or prefixal formatives also remain without an additional adverbial orientation, e.g., približati ('to get near'), razdeliti ('to distribute'), ohladiti - shladiti ('to cool down'), boljšati - izboljševati/poboljševati ('to improve'), etc.

In accord with expectations, the highest degree (especially spatial-temporal) of interdependence between prefixal morphemes and prepositional morphemes is found in verbs of physical and mental states, e.g., prebivati na/v/pri ('to live on/in/at'), prenočevati $v /$ pri ('to spend the night in/at'), preživotariti skozi ('to eke out a living through'), preživeti na/v/pri/skozi ('to survive on/in/at/through'), obležati na/za ('to remain lying in/behind'), in verbs of motion, e.g., povzpeti se na ('to ascend'), poleteti $v$ ('to fly into'), podrsovati pri ('to slide at'), preiti na ('to switch to'), prejadrati na ('to sail on'), prejadrati (čez) ocean ('to sail across the ocean'), preletavati po/nal čez ('to fly in/over'), and in verbs with a stressed semantic component of co-originating/co-occurrence/appurtenance, e.g., podedovati za/od/po ('to inherit'), pocukati za ('to tug at'), podariti za ('to give/donate for'), počakati z ('to wait with'), povasovati pri ('to visit at'), omejiti na ('to limit to'), etc. As expected, the lowest degree of interdependence between prefixal morphemes and prepositional morphemes is found 
in verbs with a stressed semantic component of change in property, e.g., pokriti $z$ ('to cover with'), pogladiti $z$ ('to smooth out with'), and in verbs denoting changes in general, e.g., povzpeti se na/v ('to ascend (on)to'), povečati se za/v ('to increase in'), etc.

In bi- and multi-morphemic complex prefixal formatives the semantic-syntactic base hierarchy is transformed and clearly expressed between adverbial adjuncts and qualitative complements. The shift in the meaning of the prefixal formative to the last far-left prefixal morpheme, e.g., sprevreči : prevreč $i$, doprinesti : prinesti, predomisliti se 'premisliti se' ('to change one's mind') : domisliti se, oprijemati : prijemati, vpoklicati : poklicati, - the last far-left prefixal morpheme (usually due to at least partial overlapping) semantically prevails and, as a consequence, the morpheme closer to the root is (gradually) elided, e.g., prepogibati $>$ pregibati, razpodeliti $>$ razdeliti, etc. In some verbs the semantic/word-formational relation of otherwise semantically equal verbs has been preserved, e.g., razpodeliti* (star.) : razdeliti : porazdeliti, etc. 


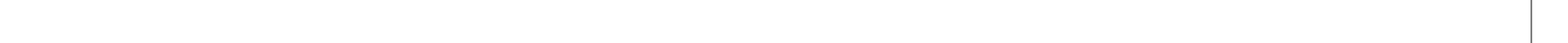

